\title{
Inovasi UMKM Pendukung Rintisan Wisata Trabas Desa Polosiri Bawen Kabupaten Semarang
}

\author{
Nila Kusumaningtyas ${ }^{1}$, Sudargo $^{1}$, Sutomo ${ }^{2}$, Yuris Setyoadi ${ }^{1}$, dan Mega Novita ${ }^{1}$ \\ ${ }^{1}$ Universitas PGRI Semarang, Indonesia, ${ }^{2}$ Universitas Darul Ulum Islamic Centre Sudirman \\ novita@upgris.ac.id
}

Received: $15^{\text {th }}$ November $2020 \mid$ Accepted: $10^{\text {th }}$ December $2020 \mid$ Published: $30^{\text {th }}$ January 2021

\section{Key word:}

Innovation; marketing; mannagement; production; information

technology

\section{$+$}

\section{Kata Kunci}

Kebiasaan hidup bersih;

tingkat pengetahuan; kebersihan dan kesehatan

\section{Abstract}

Polosiri is a village located in Bawen District, Semarang Regency. Since 2019, Polosiri has been accompanied by Universitas PGRI Semarang (UPGRIS) and Universitas Darul Ulum Islamic Centre Sudirman (UNDARIS) University to pioneer a trabas-themed tourism village. But in 2020, due to the Covid-19 pandemic, the community service activities will be focused on strengthening KWT Lestari Sejahtera as a unit that will support the trabas-themed tourism village. Even though they already have a brand product, their business management and the production capacity were yet maximized. Assistance is needed to innovate in many aspects such as product diversification, production-process innovation and marketing innovation. The method used in this work is community development which places citizens as both object and subject. Various appropriate technologies such as Bimo-CF starter the key point to make mocaf, automatic cassava cutting machine, automatic flour powder machine, continuous sealer machine are adopted.

\section{Abstrak}

Polosiri adalah sebuah desa yang terletak di Kecamatan Bawen Kabupaten Semarang. Sejak tahun 2019, Desa Polosiri didampingi tim pengabdi yang berasal dari Universitas PGRI Semarang (UPGRIS) dan Universitas Darul Ulum Islamic Centre Sudirman (UNDARIS) merintis desa wisata bertema trabas. Tetapi pada tahun 2020, karena pandemi Covid-19, kegiatan pengabdian kepada masyarakat difokuskan pada penguatan KWT Lestari Sejahtera sebagai pendukung rintisan wisata trabas. Meskipun sudah memiliki produk dan brand, tetapi manajemen usaha dan kapasitas produksinya belum maksimal. Metode yang digunakan dalam kegiatan ini adalah "community development" yang menempatkan warga sebagai objek sekaligus subjek. Pendampingan dilakukan untuk berinovasi di banyak aspek seperti diversivikasi produk, inovasi proses produksi dan inovasi pemasaran. Berbagai teknologi tepat guna seperti starter Bimo-CF yang menjadi kunci dalam pembuatan mocaf, mesin pemotong singkong otomatis, mesin penepung otomatis, mesin continuous sealer diadopsi. 


\section{PENDAHULUAN}

Polosiri adalah sebuah desa yang terletak di Kecamatan Bawen Kabupaten Semarang. Sejak tahun 2019, Desa Polosiri didampingi tim pengabdi yang berasal dari Universitas PGRI Semarang (UPGRIS) dan Universitas Darul Ulum Islamic Centre Sudirman (UNDARIS) merintis desa wisata bertema trabas. Sudah lebih dari 7 tahun, Desa Polosiri sering menjadi tujuan para pecinta trabas untuk menyalurkan hobi. Berawal dari keresahan warga akibat aktifitas pecinta trabas yang sering kali mengganggu dan merusak lingkungan, kini Desa Polosiri berdamai dan mengambil sisi positif dengan memanfaatkan peluang ekonomi dari kegiatan tersebut. Pemetaan lokasi trabas dan perijinan terkait kepemilikan lahan telah selesai dilaksanakan pada tahun 2019. Namun karena pandemi Covid-19, sejak bulan Maret 2020 kegiatan trabas di desa Polosiri dilarang. Hal ini terpaksa dilakukan sesuai arahan pemerintah untuk membatasi kegiatan dan stay at home.

Dampak pandemi virus korona telah merugikan banyak pihak (Soehardi, dkk 2020), khususnya bidang pariwisata seperti yang saat ini dirintis masyarakat Desa Polosiri. Bali, pusat pariwisata Indonesia, menurut Gurbernur I Wayan Koster, dari yang sebelumnya 6.3 juta jiwa sekarang tidak ada satupun wisatawan asing yang datang. Hal ini dapat dipahami karena tidak ada orang yang berwisata dengan mengambil resiko kematia. Oleh sebab itu, perlu strategi tepat untuk dapat dengan cepat memulihkan keadaan ekonomi bidang pariwisata (Djausal \& Muflihah, 2020; Herdiana, 2020). Pariwisata ke depan adalah pariwisata yang penuh inovasi dan penuh kreativitas, dan juga bisa beradaptasi dengan kemajuan teknologi (Paramita \& Putra, 2020). Salah satu caranya adalah dengan penguatan sektor Usaha Mikro, Kecil, dan Menengah (UMKM) pendukung wisata.

Pada dasarnya sebelum ada gagasan rintisan desa wisata trabas, Desa Polosiri sudah memiliki beberapa potensi UMKM. Produk yang ditawarkan berupa minuman empon-empon, makanan kecil berbasis umbi-umbian dan jamur, nugget berbasis ayam, lele dan tempe, serta hiasan ukir dan anyaman yang memiliki nilai seni yang tinggi. Pengelolaan usahanya memang belum maksimal, tetapi omset penjualan dalam 4 bulan sejak pandemi turun drastis. Dari permasalahan tersebut, kegiatan pengabdian kepada masyarakat yang didanai oleh Kemenristek/ BRIN melalui skema Program Kemitraan Wilayah (PKW) ini difokuskan untuk pendampingan terhadap UMKM Desa Polosiri untuk memulihkan perekonomiannya. Tujuan dari kegiatan ini adalah menyiapkan momentum 
kebangkitan pariwisata di tahun 2021. Inovasi-inovasi di berbagai aspek seperti pada produksi, pemasaran dan diversivikasi produk dilakukan untuk meningkatkan daya saing UMKM.

\section{METODE}

Sasaran utama kegiatan ini adalah kelompok Kelompok Wanita Tani (KWT) Lestari Sejahtera. Saat ini KWT Lestari Sejahtera memiliki anggota lebih dari 15 orang dari yang tadinya hanya 5 orang. Jumlah tersebut meningkat pesat semenjak pelaksanaan program PKW di tahun 2019. Dalam kegiatan pendampingan UMKM ini, pendekatan yang digunakan adalah Community Development (Phillips \& Pittman, 2014).

Metode ini merupakan pendekatan yang berorientasi kepada upaya-upaya pengembangan pemberdayaan masyarakat dengan menjadikan masyarakat sebagai subyek dan sekaligus obyek pembangunan dan melibatkan mereka secara langsung dalam berbagai kegiatan pengabdian masyarakat sebagai upaya meningkatkan peran serta mereka dalam pembangunan demi kepentingan mereka sendiri. Tahapan dalam kegiatan ini dilakukan dengan (1) identifikasi kebutuhan masyarakat, (2) perancangan, (3) pembuatan, (4) pendampingan operasional. Pertama tahap identifikasi kebutuhan masyarakat, wawancara dan observasi langsung dilakukan kepada mitra. Kedua, tahap perancangan dilakukan dengan cara studi literatur dan diskusi. Tahap ketiga, pembuatan, dilakukan dengan cara sosialisasi, praktek secara langsung dan diskusi. Terakhir adalah pendampingan yang dilakukan dengan metode praktek mandiri dan tanya jawab secara langsung.

\section{HASIL DAN PEMBAHASAN \\ Pelatihan manajemen UMKM}

Permasalahan utama yang dihadapi oleh pelaku UMKM biasanya adalah di sisi manajemen usaha. Secara garis besar manajemen UMKM meliputi empat aspek yaitu keuangan, produksi/ operasional, pemasaran dan Sumber Daya Manusia (SDM) (Bismala, 2016; Humaira \& Sagoro, 2018).

Pada aspek keuangan, biasanya KWT Lestari Sejahtera belum mampu memisahkan antara keuangan usaha dengan keuangan pribadi. Kondisi ini diperparah dengan tidak adanya pencatatan transaksi keuangan sehingga perputaran modal usaha menjadi tidak jelas dan tidak terkontrol. Di aspek produksi/ operasional, dalam perkembangannya KWT Lestari Sejahtera mengalami berbagai kendala teknis dan teknologi seperti kapasitas produksinya masih sedikit. Mereka hanya memiliki persediaan sesuai dengan kemampuan 
modalnya. Mereka tidak mau teknologi.

mengandalkan pinjaman dari bank, karena

Karena biasanya SDM yang direkrut cukup sulitnya proses peminjaman dan pelaku tidak ingin tergantung pada pinjaman modal. Di sisi lain kreativitas menciptakan produk-produk baru juga masih sangat terbatas. Lingkup pemasaran KWT Lestari Sejahtera juga masih sangat terbatas dalam RT, RW maupun desa. Pola beli konsumen saat pandemi cenderung menggunakan pola Less Contact Economy (LCE) atau ekonomi minim kontak. Sedangkan di aspek SDM anggota KWT Lestari Sejahtera masih tergolong berasal dari daerah sekitar wilayah usahanya, walaupun tanpa keahlian yang diperlukan. Pelatihan manajemen UMKM yang dilaksanakan pada tanggal 3 Agustus 2020 di Balai Desa Polosiri (Gambar 1) dengan mengikuti protokol kesehatan secara ketat bertujuan untuk memberikan motivasi dan solusi untuk meningkatkan daya saing KWT Lestari Sejahtera. Materi pada pelatihan tersebut meliputi manajemen usaha, manajemen pemasaran, berpendidikan rendah dan belum melek manajemen produksi dan manajemen SDM.

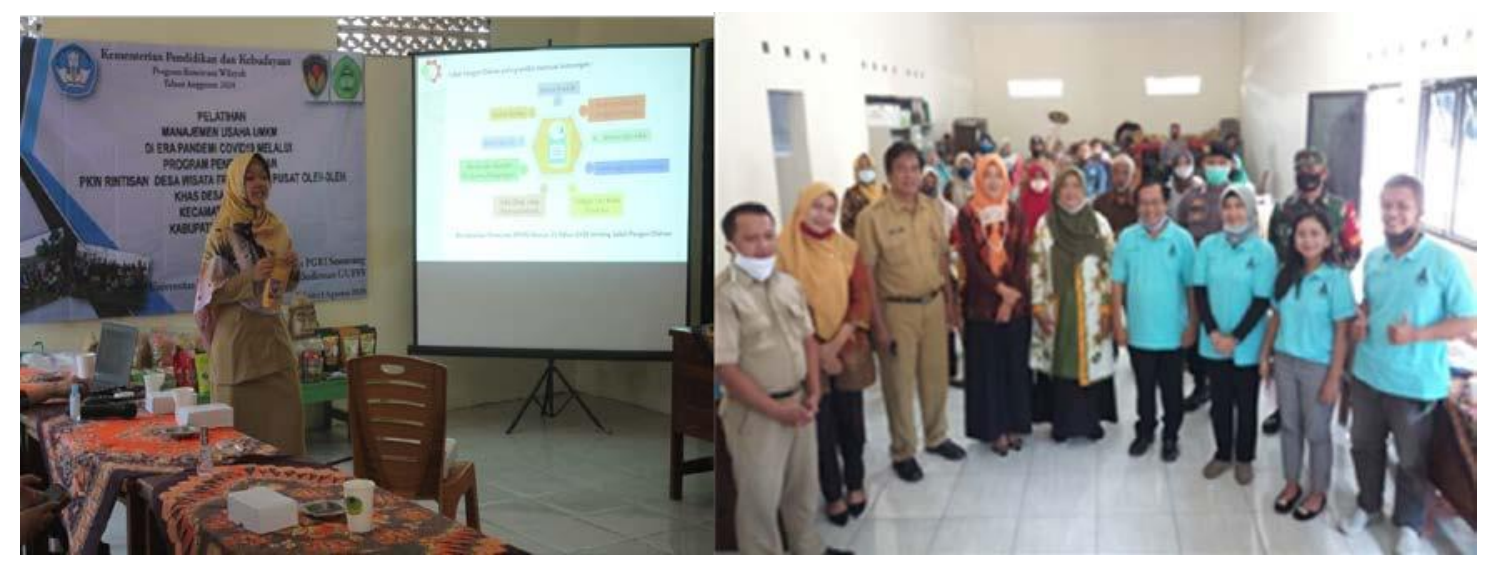

Gambar 1. Pelatihan manajemen UMKM oleh Dinas Koperasi, Usaha Mikro, Perindustrian dan Perdagangan Kabupaten Semarang di Balai Desa Polosiri tanggal 3 Agustus 2020 dengan mematuhi protokol kesehatan.

\section{Diversifikasi produk}

Diversifikasi produk merupakan usaha yang dilakukan perusahaan untuk penganekaragaman produk atau jasa dengan jalan menciptakan produk atau jasa baru agar sesuai dengan selera dan kebutuhan konsumen sehingga dapat meningkatkan penjualan. Karena Desa
Polosiri memiliki hasil singkong yang cukup banyak, KWT Lestari Sejahtera berinisiatif memproduksi tepung modified cassava flour (mocaf). Mocaf atau yang biasa dikenal dengan beras cerdas adalah tepung ubi kayu (Manihot esculenta crantz) yang dimodifikasi sedemikian rupa yang ditemukan oleh Prof. Achmad Subagio dari 
Universitas Jember (Subagio, 2012

Ruriani, dkk., 2013).

Berdasarkan data Kemenkes RI pada Tabel komposisi Pangan Indonsia (TKPI), setiap 100 gram tepung mocaf mengandung $15,8 \mathrm{mg}$ besi, 6,0 gram serat dan 403,0 mg kalium (Indonesia, 2013). Ini menunjukkan bahwa kandungan besi, serat dan kalium termasuk tinggi dan cukup tinggi. Dengan kandungan besi yang tinggi akan memperkuat produksi hemoglobin. Tepung ini dapat digunakan sebagai tepung terigu yang aman bagi penderita alergi dan anak autis, memiliki Kadar lemak rendah, mengandung hormon fitoestrogen yang dapat mencegah proses menopos dan zat skopoletin yang dapat mencegah tumbuhnya kanker. Langkah-langkah pembuatan tepung mocaf ditujukkan pada

Gambar 2. Pertama singkong dikupas, dicuci dan dibersihkan lendirnya. Kedua dipotong-potong untuk selanjutnya direndam dan difermentasi dengan mencampurkan starter enzim mocaf selama 8-12 jam. Ketiga, tiriskan singkong yang telah terfermentasi lalu keringkan hingga kadar air di bawah $10 \%$. Keempat, giling risan singkong kering yang telah terfermentasi tersebut dengan mesin penepung beras. Ayak hasil penepungan dengan saringan 80 mesh dan kemas dalam wadah plastik sehingga siap untuk dijual.

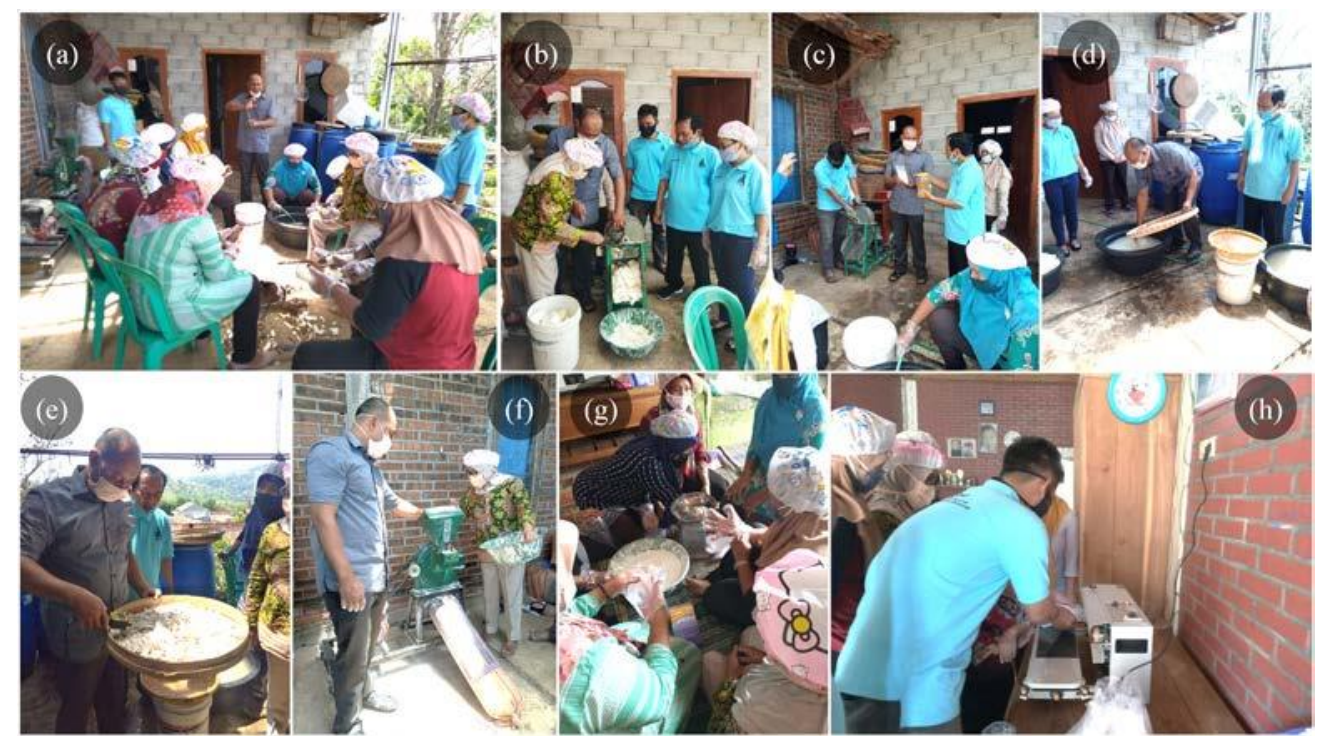

Gambar 2. Praktek langsung pembuatan tepung mocaf yang meliputi (a) pengupasan singkong, (b) perajangan, (c) fermentasi, (d) penjemuran, (e) pengecekan kadar air, (f) penepungan, (g) pengemasan dan (h) penyegelan

\section{Inovasi proses produksi}

Inovasi produksi adalah suatu kegiatan untuk melakukan perubahaan dalam proses produksi supaya dapat menekan biaya produksi dan operasional juga memperbanyak jumlah produksi dan meningkatkan kualitas produk. Beberapa mesin Teknologi Tepat Guna (TTG) yang 
menunjang kegiatan produksi seperti starter enzim fermentasi mocaf, mesin perajang singkong, mesin penepung (Batubara, 2014), dan mesin continuous sealer untuk pengemasan diimplementasikan untuk menekan biaya produksi. Starter Bimo-CF adalah bibit atau starter tepung mocaf untuk fermentasi pada proses pembuatan tepung mocaf atau cassava termodifikasi secara biologi. Starter terdiri dari bahan pembawa dan bahan aktif bakteri asam laktat.

Faktor yang harus diperhatikan adalah suhu dan konsentrasi starter (Yerizam, 2020). Mesin perajang singkong bertenaga listrik mudah digunakan untuk keperluan merajang singkong dengan kecepatan $30-50 \mathrm{Kg} /$ jam yang akan dibuat menjadi keripik. Mesin penepung atau disk mill adalah mesin selep yang didesain untuk menepungkan aneka komoditi dengan kecepatan 10-15 Kg/ jam, dalam hal ini potongan singkong kering terfermentasi. Sedangkan mesin continuous sealer adalah mesin pengemas dan penyegel yang biasanya digunakan untuk menyegel produk yang kemasannya terbuat dari jenis bahan thermoplastic. Mesin ini menggunakan daya sebesar 500 watt.

Dengan menggunakan mesin-mesin TTG yang sudah disebutkan di atas, dihrapkan kapasitas produksi KWT Lestari Sejahtera meningkat drastis yang menjamin ketersediaan barang (Khusnawati \&
Prasetyo, 2016; Rahmiyati, 2015; Rahman, dkk., 2020).

\section{Inovasi pemasaran berbasis teknologi informasi}

Inovasi pemasaran adalah penerapan metode pemasaran yang baru atau peningkatan signifikan pada pengemasan atau desain produk, penempatan produk, promosi produk, atau harga (Chen, 2006). Inovasi di bidang pemasaran menjadi tiga. Pertama inovasi yang memungkinkan mengungguli pesaing (outsmarting the competitor). Inovasi jenis ini adalah inovasi yang paling dasar dan paling gampang. Caranya dapat bermacam-macam, misalnya dengan menciptakan produk dengan kualitas yang lebih baik, atau harganya lebih murah, atau bisa juga memberikan layanan yang lebih cepat dengan kata lain "be better, be cheaper, be faster". Sayangnya inovasi yang pertama tidak cukup, perlu inovasi kedua adalah harus beda dan unik atau "being different".

Lebih lengkapnya jika dapat melakukan inovasi yang ketiga yaitu mentransformasi usaha atau "transforming the company" bisa orang, organisasi, system, kompetensi, strategi, dll. Langkah awal yang paling mungkin dilakukan KWT Lestari Sejahtera adalah menggunakan strategi pemasaran berbasis online untuk memperluas wilayah pemasaran. Saat ini KWT Lestari Sejahtera memiliki brand 
BuTet untuk produk minuman herbal 1_serbukinstan/, ditunjukkan pada Gambar berbasis empon-empon dan sudah 3. Desain kemasan produk mocaf yang telah melakukan perjualan secara online di laman https://butet.company.site/. Selain itu, KWT dibuat merujuk teori desain grafis Lestari Sejahtera juga memanfaatan social media seperti instagram sebagai media pemasaran ditunjukkan pada Gambar 4. Secara visual, desain kemasan tepung mocaf dominan warna putih dan hijau. Secara fungsional, https://www.instagram.com/minumanherba
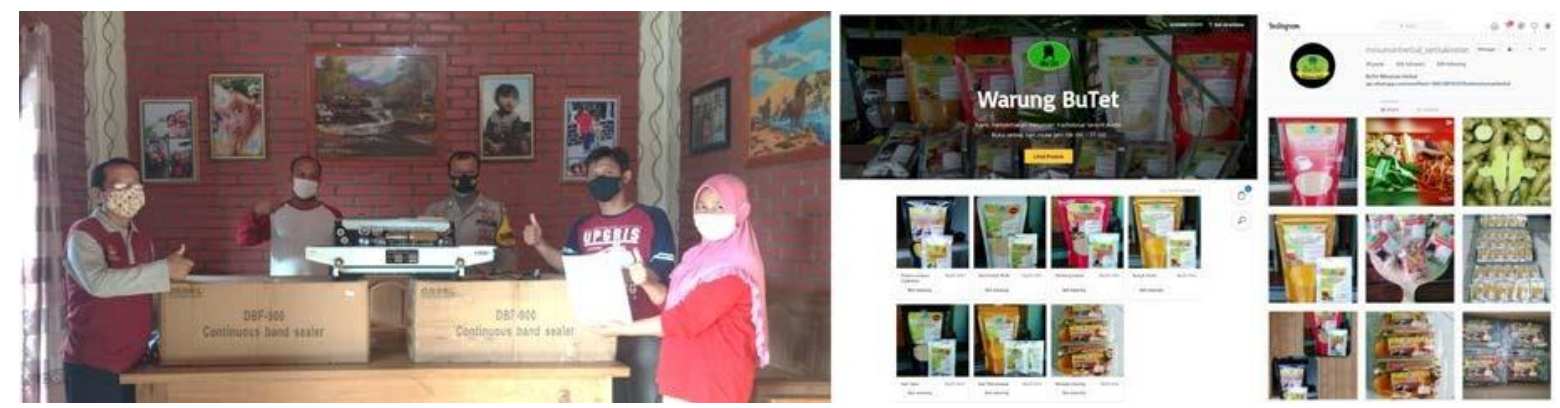

Gambar 3. Serah terima Teknologi Tepat Guna (TTG) kepada Kelompok Wanita Tani (KWT) Lestari Sejahtera disaksikan oleh Kepala Desa Polosiri Bapak Nurgiyanto dan Bhayangkara Pembina Keamanan dan Ketertiban Masyarakat (Bhabinkamtibmas) Bapak Priyo.
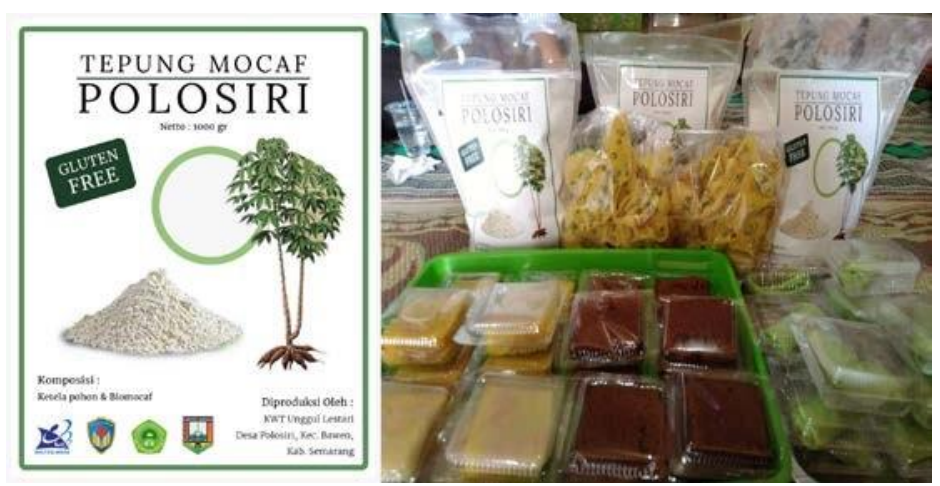

Gambar 4. Desain kemasan tepung mocaf dan produk olahan pangannya

\section{SIMPULAN}

Kegiatan pengabdian kepada masyarakat dengan pendanaan

Kemenristek/ BRIN melalui skema Progam Kemitraan Wilayah (PKW) telah dilaksanakan di Desa Polosiri, Kecamatan Bawen, Kabupaten Semarang, Jawa Tengah. Rintisan desa wisata trabas yang telah direncanakan sejak tahun 2019, terpaksa ditunda karena pandemi Covid-19. Perhatian difokuskan terhadap penguatan UMKM mitra, dalam hal ini KWT Lestari Sejahtera sebagai pendukung rintisan desa wisata trabas. Untuk membantu memulihkan perekonomian warga pasca Covid-19, sosialisasi dan pelatihan manajemen UMKM dilakukan. Inovasi di berbagai sektor seperti diversivikasi produk, 
inovasi proses produksi dan inovasi pemasaran berbasis teknologi informasi didorong untuk menyiapkan momentum kebangkitan pariwisata di tahun 2021.

\section{SARAN}

Berbagai TTG diadopsi untuk tujuan pemberdayaan, peningkatan dan pengembangan produski KWT Lesatari Sejahtera Desa Polosiri, Kecamatan Bawen Kabupatne Semarang. Namun, teknologi pengembangan UMKM tidak terbatas pada aspek-aspek yang telah dijelaskan di atas. Karena teknologi terus berkembang dengan pesat seiring dengan kemajuan jaman, maka sangat penting bagi UMKM untuk terus mengikuti perkembangan teknnologi dan menerapkannya dalam praktik bisnis nyata.

\section{UCAPAN TERIMA KASIH}

Kegiatan pengabdian kepada masyarakat ini didanai oleh Kementerian Riset dan Teknologi/Badan Riset dan Inovasi Nasional (Kemenristek/BRIN) Republik Indonesia melalui skema Program Kemitraan Wilayah (PKW) tahun 2020. Terimakasih atas dukungan dari pemerintah dan segenap warga Desa Polosiri, Kecamatan Bawen, Kabupaten Semarang, Jawa Tengah yang menjadi penentu suksesnya kegiatan ini.

\section{DAFTAR PUSTAKA}

Batubara, H., Rahayuni, T., \& Budiman, R. (2014). Rancang Bangun Mesin Perajang Singkong Untuk Meningkatkan Efisiensi Waktu Perajangan Dan Menurunkan Keluahan Musculoskeletal. Jurnal ELKHA, 6(1).

Bismala, L. (2016). Model Manajemen Usaha Mikro Kecil dan Menengah (UMKM) untuk Meningkatkan Efektivitas Usaha Kecil Menengah. Jurnal Entrepreneur dan Entrepreneurship, 5(1), 19-26.

Chen, Y. (2006). Marketing innovation. Journal of Economics \& Management Strategy, 15(1), 101123.

Djausal, G. P., Larasati, A., \& Muflihah, L. (2020). Strategi Pariwisata Ekologis Dalam Tantangan Masa Pandemik Covid-19. Jurnal Perspektif Bisnis, 3(1), 57-61.

Herdiana, D. (2020). Rekomendasi Kebijakan Pemulihan Pariwisata Pasca Wabah Corona Virus Disease 2019 (Covid-19) di Kota Bandung. Jurnal Master Pariwisata (JUMPA), 1-30.

Humaira, I., \& Sagoro, E. M. (2018).

Pengaruh pengetahuan keuangan, sikap keuangan, dan kepribadian terhadap perilaku manajemen 
keuangan pada pelaku UMKM sentra

kerajinan batik KABUPATEN

BANTUL. Nominal: Barometer Riset

Akuntansi dan Manajemen, 7(1), 96-

110. 